\section{Bioética, ciências e tecnologia - Democratização da informação digital numa perspectiva bioética}

Cardozo, E O

Hospital Paranaense de Otorrinolaringologia IPO / PUC/PR elisakrill@hotmail.com

\section{Chiesa, D P}

Pontifícia Universidade Católica do Paraná- PUC

\section{Sanches, M A}

Programa de Pós-graduação em Bioética; Pontifícia Universidade Católica do Paraná- PUC

PALAVRAS-CHAVE: Informação, Bioética, Tecnologia .

INTRODUÇÃO: Cada época histórica é marcada por certas palavras-chave que conseguem captar o espirito do seu tempo, tivemos a Era Industrial $\mathrm{e}$ hoje vivemos na denominada Era da Informação, quando a velocidade da produção de notícias no mundo é potencializada pela facilidade com que celulares, tablets, blogs e redes sociais propagam fotos e textos em escala global. Esse fenômeno acabou por retirar dos meios de comunicação tradicionais o monopólio da produção de informação. Atualmente a informação e o processo de produção da mesma estão pulverizados num universo com mais de 7 bilhões de pessoas, cada qual tornando-se em um potencial veículo de comunicação. A internet é o maior experimento da historia envolvendo anarquia. Essa nova capacidade de livre expressão e movimento de informação gerou essa paisagem que conhecemos atualmente. Considere também que a ausencia de um controle hierarquico assim permitindo: fraudes online, campanhas de bullyng, sites de grupos de apologia ao ódio e preconceito. É neste contexto que o trabalho é desenvolvido, na busca de protocolos que forneçam segurança na busca de informações. MÉTODOLOGIA: Revisão Teorica CONCLUSÃO: A internet é o maior espaco sem governo que conhecemos na atualidade. Os proximos momentos da nossa evolução tecnologica prevé diversas transformações que já estão visiveis e presentes no nosso dia a dia como: carros sem motoristas (IA), maquinas que fazem a limpeza de sua casa, geladeiras inteligentes que fazem lista e compras de mercado e diversos outros exemplos. Uma das primeiras definições do termo Bioética dada por Potter foi: Hoje somos desafiados a confrontar essas questões complexas sem as tradicionais normativa ou leis para se valer como um primeiro passo. Essa perspectiva de pensamento não deixa de ser uma profunda provocação e questionamento para que todos busquem um mundo melhor, e esse mundo em questão se trata do conhecimento, da obtenção da informação. Temos como enorme desafio refletir, aprofundar e elaborar protocolos seguros para divulgação e disseminação de informações em meios eletrônicos, protocolos estes que sejam ao mesmo tempo promotores de inclusão e que garanta a promoção e defesa do pensamento, principalmente dos mais vulneráveis, trazendo assim um futuro mais digno para toda a humanidade.

\section{REFERÊNCIAS}

[1] CASTELl, M. Redes de Indignação e Esperança: Movimentos Sociais na Era da Internet. 1. ed. Rio de Janeiro: Zahar, 2013.

[2] FONTES, E. Políticas e normas de segurança de informação. Rio de Janeiro: Brasport, 2012.

[3] GOLDIM JR, X. O Princípio da Precaução. Institut Servier. La prévention et la protection dans la société du risque: le principe de précaution. Amsterdam: Elsevier, 2001. Disponível em: <http://www.bioetica.ufrgs.br/precau.htm.>

[4] LEVY, P. A. Cibercultura. São Paulo: Ed. 34, 2007.

[5] SIQUEIRA, H. S. G. Globalização e Autonomia - os limites e as possibilidades. Extensão Rural - Santa Maria: UFSM, n. 8, p. 99-122, jan.-dez. 2002. 